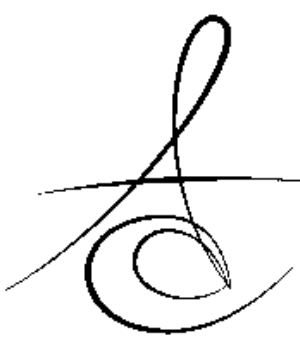

\section{BIOMECHANICAL COMPARISON OF STRESSES GENERATED THROUGH TWO DIFFERENT DENTAL IMPLANT DESIGNS TO BE APPLIED IN AUGMENTED MAXILLARY SINUS}

\section{OGMENTE MAKSİLLER SİNUS BÖLGESİNE UYGULANAN IKI FARKLI IMPLANT TASARIMININ OLUŞTURDUĞU STRESLERIN BIYOMEKANIK OLARAK KARŞILAŞTIRILMASI}

Dr. Dt. Onur ADEMHAN*
Yrd. Doç. Dr. Sercan KÜçÜKKURT**

Makale Kodu/Article code: 2946

Prof. Dr. Sedat CETİNER*

\author{
Makale Gönderilme tarihi: 25.07.2016
}

Kabul Tarihi; 26.01 .2017

\section{ABSTRACT}

Aim: The purpose of this study is to compare the stress formations of two different implant designs in augmented maxillary sinuses using the three-dimensional (3D) finite elements analysis method. Material and Methods: A 3D model of atrophic posterior maxilla involving the maxillary sinus was created with computer software by using a computerized tomography image of a real patient. Similarly, implants in two different designs, prosthetic superstructures, and graft applied maxillary sinus were simulated. Four groups were obtained in total with two types of implants (Ankyos: $A_{\text {, }}$ Xive: $X$ ) with different designs, and two different scenerarios including control models ( $\mathrm{A} 1$ and $\mathrm{X} 1$ ) without maxillary sinuses and maxilla models with grafted maxillary sinuses (A2 and $\mathrm{X} 2$ ). In these groups, stress analysis on cortical bone, trabecular bone and graft material were conducted under the forces close to real masticatory forces. Results: Tensiontype stresses in cortical bone as a result of vertical loading, was lower in $X$ Groups. When control group models were compared with maxillar sinus augmentation (MSA) models, no significant difference was revealed. In trabecular bone and graft material, no significant difference was revealed except for the A2 model which generated lower stresses. Compression-type stresses in cortical bone as a result of vertical loading, less stress formation was observed in Group A models. When MSA models were compared, X2 group caused more stress formation. In control groups the results were similar. In trabecular bone and graft material, no significant difference was found. Tension-type stresses in cortical bone as a result of oblique loading, no significant differences were revealed. In trabecular bone and graft material, in all models, Group A caused significantly less stress. Compression-type stresses in cortical bone as a result of oblique loading, significantly less stress formation was measured in Group A models. When MSA models were compared, the implant in the $\mathrm{X} 2$ group led to more stress formation. In the control groups, the results were similar. In the tension-type stresses in trabecular bone and graft material, no significant difference was revealed except for the A2 model which led to less stress. The stress values formed on the graft material were quite close. Conclusion: Implant design with "V" shaped thread (Group X) caused more stress formation in almost all conditions, except vertical compression stresses caused by vertical loadings, in comparison to the models with square shaped thread form implants (Group A). Keywords: Dental implants; Finite element analysis; Implant design; Sinus floor augmentation

\section{öz}

Amaç: Bu çalışmanın amacı 3 boyutlu (3D) sonlu elemanlar stres analizi yöntemini kullanarak, posterior maksiller bölgede greft kullanılarak sinüs tabanı yükseltilmesi yapıımış örneklerde iki farklı implant tasarımının stres oluşumuna etkilerini karşılaştırmaktır. Gereç Ve Yöntem: Gerçek bir hastaya ait bilgisayarlı tomografi görüntüsü kullanılarak maksiller sinüsü de içeren atrofik posterior maksillanın 3D modeli bilgisayar yazılımları ile oluşturulmuştur. Benzer şekilde iki farklı tasarımda implant modelleri, protetik üst yapılar ve maksiller sinüse uygulanmak üzere greft materyali canlandırımıştır. Farklı tasarıma sahip iki tip implant (Ankyos: A, Xive: X), maksiller sinüsün ihmal edildiği kontrol modellerine ( $A 1$ ve $X 1$ ) ve içerisine greft materyali yerleştirilen sinuse sahip maksilla modellerine yerleştirilerek (A2 ve X2) toplamda 4 grup elde edilmiştir. Oluşturulan bu gruplarda, teknik olanakların elverdiği ölçüde gerçek yaşamdaki çiğneme kuvvetlerine benzer kuvvetler altında kortikal, trabeküler ve greft materyali üzerinde oluşan streslerin analizi yapılmıştır. Bulgular: Vertikal kuvvetler karşısında kortikal kemikte oluşan gerilme stresleri $\mathrm{X}$ gruplarında daha düşük bulunmuştur. Kontrol grupları ile sinus ogmentasyonu (SO) grupları karşılaştırıldığında anlamlı bir fark oluşmamıştır. Trabekuler kemik ve greft materyalinde daha düşük stress oluşturan A2 modeli hariç diğer modellerde anlamlı fark oluşmamıştır. Vertikal kuvvetlere karşı oluşan sıkışma streslerinde, kortikal kemikte A gruplarında daha düşük stresler ölçülmüştür. SO gruplarında $X 2$ modelinde daha yüksek stress oluşmuştur. Kontrol gruplarında ise fark gözlenmemiştir. Trabeküler kemik ve greft materyalinde ise bir fark gözlenmemiştir. Oblik kuvvetler sonucu oluşan gerilme steslerinde, kortikal kemikte bir fark bulunamamıştır. Trabeküler kemik ve greft materyalinde ise A grubunda düşük stress değeleri oluşmuştur. Oblik kuvvetlere karşı oluşan sıkışma tipi streslerde, kortikal kemikte A gruplarında düşük stresler gözlenmiştir. SO gruplarında X2 modeli daha yüksek stress oluşturmuştur. Kontrol grupları arasında ise fark bulunamamıştır. Oblik kuvvetlere karşı oluşan gerilme streslerinde, trabeküler kemik ve greft materyalinde, daha düşük stresler oluşan A2 modeli haricinde fark gözlenmemiştir. Sonuç: Üçgen yiv tasarımlı implantlara (Grup X) sahip modellerde, kare yiv tasarımında implantlara (Grup A) sahip modellere göre, vertikal kuvvetler sonucu oluşan sıkışma stresleri dışında, neredeyse her koşulda daha fazla stres oluşumu gözlenmiştir.

Anahtar Kelimeler: Dental implant; Implant tasarımı; Sinüs taban yükseltmesi; Sınırlı eleman analizi

\footnotetext{
*Gazi University, Faculty of Dentistry, Department of Oral and Maxillofacial Surgery

${ }^{* *}$ Istanbul Aydın University, Faculty of Dentistry, Department of Oral and Maxillofacial Surgery
} 


\section{INTRODUCTION}

In contemporary dentistry, dental implants have become a routine treatment due to aesthetic and phonetic contribution, in addition to fulfilling the function of the lost natural teeth ${ }^{1}$. In the posterior maxillary region, pneumatization of maxillary sinuses usually restricts implant application. In such cases, in order to increase the amount of bone, maxillary sinus augmentation (MSA) procedure is performed frequently ${ }^{2}$.

Biomechanical rules and prosthetic planning largely affect the success of implant-supported prostheses. No matter how successful the surgical technique is, the loadings over the physiological limits are the main reason of the pathological bone resorption formed around the implant. The factors such as the length of the applied implants, diameter, features and designs of threads directly affect the forces and stresses that come over implants and surrounding tissues. Elimination of the overloads that may come on the bone-implant connection is achieved with accurate diagnosis, good treatment planning and implant choice in the designs which can provide the appropriate force transmission ${ }^{3,4}$.

In the literature, there is very limited knowledge related to the purpose of placing an implant in appropriate design to the MSA region. This finite element analysis study is designed by the consideration of the effect of the change of thread features on stress generation by keeping the implant diameter and length constant.

\section{MATERIAL AND METHOD}

In this study, a maxilla model was performed after a real patient's computerized tomography (CT) data was converted to DICOM format (Digital Imaging and Communications in Medicine). Two types of implants with the same diameter and length, having same surface and material feature but different in designs (Xive and Anklyos, Dentsply Implants Manufacturing $\mathrm{GmbH}$, Mannheim- Germany) and two types of prosthetic superstructures (abutments) compatible with the implants were used. Xive implants has "V" shaped aggresive thread design, while Ankylos has a square shaped passive thread design (Table 1). Implants and abutments were scanned as 3D at the macro scale with a

Nextengine 3D scanner (NextEngine, Inc. 401 Wildshire Blvd, Ninth Floor Santa Monica, California 90401), the image data obtained in the stereolithographic format was sent to the Rhinoceros 5.0 software (3670 Woodland Park Ave. N, Seattle, WA 98103 USA), and implant models were obtained. For the model stimulation, Marc 2013 (MSC Software Corporation, Santa Ana, Ca, USA) computer program was used. Wheeler's ${ }^{5}$ data was taken as reference for determination of the size and morphologies of the crowns on implants.

Table 1. Properties of dental implants used in the study

\begin{tabular}{|l|l|l|l|l|}
\hline & Width & Length & $\begin{array}{c}\text { Thread } \\
\text { Shape }\end{array}$ & $\begin{array}{c}\text { Thread } \\
\text { Type }\end{array}$ \\
\hline XIVE & $4.5 \mathrm{~mm}$ & $11 \mathrm{~mm}$ & "V" Form & Agressive \\
\hline ANKYLOS & $4.5 \mathrm{~mm}$ & $11 \mathrm{~mm}$ & $\begin{array}{l}\text { Square } \\
\text { Shape }\end{array}$ & Passive \\
\hline
\end{tabular}

In the graft implemented models, the entire implant surfaces, which are in the maxillary sinuses, were modeled as covered with grafting and by placing into the correct coordinates spatially, and they were combined with the system elements of bone tissue. In the identification of the graft material, similar studies were taken as referance ${ }^{6-8}$. External (crestal) cortical bone thickness of $1 \mathrm{~mm}$, trabecular bone thickness of 3.5 $\mathrm{mm}$, inner cortical bone thickness of $0.5 \mathrm{~mm}$, to be totally residual alveolar crest height of $5 \mathrm{~mm}$ were determined and $6 \mathrm{~mm}$ graft height was positioned. Then, implants in $11 \mathrm{~mm}$ length were placed. In order to form a control group in the other two models, maxillary sinus was eliminated and implants of $11 \mathrm{~mm}$ in length were placed onto the bone structure.

In order for the comparative evaluation to be clearer and simpler, study models and the implants used were grouped and named as Group X (XIVE) and Group A (ANKYLOS) by using the initials of the implant brands. Additionally, these groups were divided into subgroups among themselves (Table 2).

Table 2. Groups of the study

\begin{tabular}{|l|l|}
\hline Xive ( A Group ) & Ankylos ( B Group ) \\
\hline $\begin{array}{l}\text { Model X1, XIVE, Control } \\
\text { Model }\end{array}$ & $\begin{array}{l}\text { Model A1, ANKYLOS, Control } \\
\text { Model }\end{array}$ \\
\hline $\begin{array}{l}\text { Model X2, XIVE, Sinus Lift } \\
\text { Model }\end{array}$ & $\begin{array}{l}\text { Model A2, ANKYLOS, Sinus Lift } \\
\text { Model }\end{array}$ \\
\hline
\end{tabular}




\section{Model X1}

In model X1, Xive implants of $4.5 \mathrm{~mm}$ in diameter and $11 \mathrm{~mm}$ in length were applied to the maxillary $1^{\text {st }}$ molar tooth region. In this model which is used as a control group, maxillary sinus was eliminated (Fig. 1).

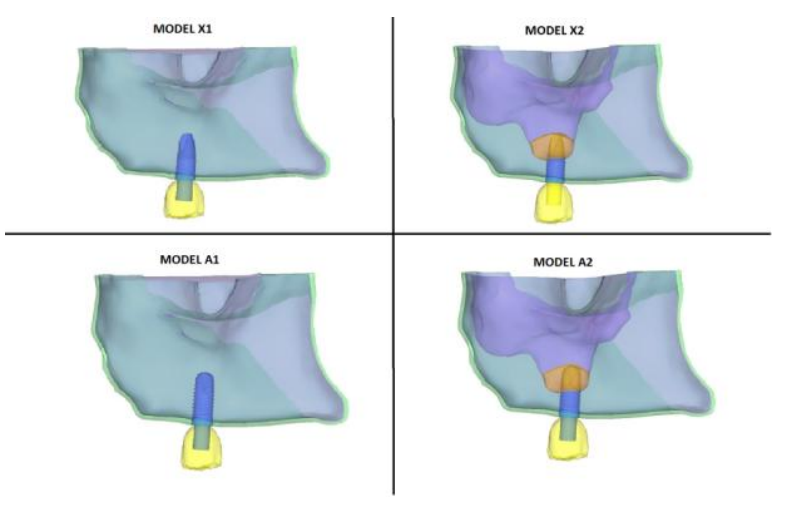

Figure 1. Simulated Models

\section{Model X2}

In model X2, Xive implants of $4.5 \mathrm{~mm}$ in diameter and $11 \mathrm{~mm}$ in length were applied to the maxillary $1^{\text {st }}$ molar tooth region. In this model, maxillary sinus was grafted up to $6 \mathrm{~mm}$ (Fig. 1).

\section{Model A1}

In model A1, Ankylos implants of $4.5 \mathrm{~mm}$ in diameter and $11 \mathrm{~mm}$ in length were applied to the maxillary $1^{\text {st }}$ molar tooth region. In this model which is used as a control group, maxillary sinus was eliminated (Fig. 1).

\section{Model A2}

In model A2, Ankylos implants of $4.5 \mathrm{~mm}$ in diameter and $11 \mathrm{~mm}$ in length were applied to the maxillary $1^{\text {st }}$ molar tooth region. In this model, maxillary sinus was grafted up to $6 \mathrm{~mm}$ (Fig. 1).

In this study, it was assumed that the graft material has completed its maturation and has reached to maximum hardness. The connection between implants with supporting tissues, implants with abutments and abutments with prostheses were designed to transmit the load transfer in a continuous manner. In similar studies ${ }^{7}$, 9 with the bone structure and graft material, it was assumed that implants are $100 \%$ osseointegrated. A bone thickness of $1 \mathrm{~mm}$ was generated on the neck region and the vestibular and lingual surfaces of the implants inserted. It was assumed that metal-supported crowns on implants have been cemented to abutments. It was neglected by considering that minimum impact to the analysis would be made due to the fineness of cement layer and the impairment of material value, and the cement gap was defined as the contact surface ${ }^{8,9}$. All materials used in this study were defined as homogeneous, isotropic and linear elastic. For the modeling of the trabecular bone, D4 bone type was used and as graft material, and xenograft graft was simulated.

Vertical Loading: A force of $300 \mathrm{~N}$ was applied to an area of approximately $2 \mathrm{~mm}^{2}$ on the long axis of the modeled tooth, perpendicular to the central fossa towards the central implant.

Oblique Loadings: A force of $300 \mathrm{~N}$ was applied to an area of approximately $2 \mathrm{~mm}^{2}$ in the distopalatinal direction to palatinal tubercle which is the functional tubercle of the modeled tooth. A loading was given at an angle of 30 degrees to the long axis of the implant in this loading condition (Fig. 2).

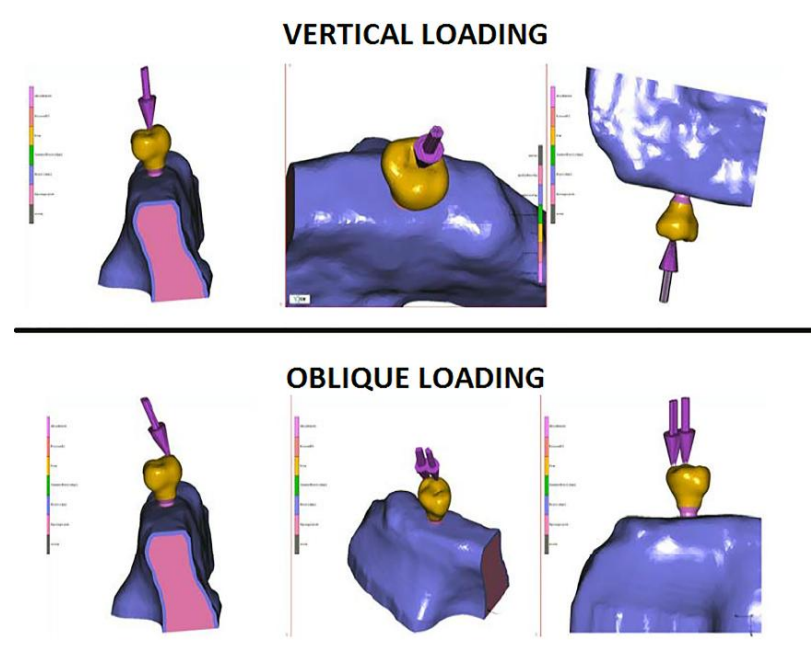

Figure 2. Loading Conditions

In this study, we benefited from Algor FEMpro (ALG, Inc. 150 Beta Drive Pittsburgh, PA 15238-2932 USA) as analysis software. While evaluating the data, the maximum principal stress (Pmax) represented tension type stresses, as for the minimum principal stress (Pmin) represented compression type of stresses ${ }^{7}$. As the data obtained from FEA emerged as a result of mathematical calculations without a variance, there were no statistical analysis of the findings. The findings obtained at the end of the analysis were evaluated using the distribution scales. All stress values were shown with color and 
quantity scales. The obtained results were comparatively evaluated afterwards.

\section{RESULTS}

As a result of the FEA conducted on the 3D models; tension and compression stresses in the different supporting tissues were measured in cortical bone, in the X2 group caused significantly more stress trabecular bone and graft material, and pmax and pmin formation compared to the A2 group. The results were values were compared in terms of megapascals (Mpa) also similar in the control groups.

(Table 3 - 4) (Fig. 3).

\section{Stress Findings in Vertical Loadings Tension (Pmax) Values}

When Group $X$ and $A$ models were compared based on the results obtained in the tension-type stresses occurring in cortical bone as a result of vertical based on the results obtained in the tension-type loading, lower stress formation was observed in Group X. stresses occurring in cortical bone as a result of oblique Also in the models with MSA, less stress formed in Group loading, no significant differences were revealed.

$X$. When control group models were compared with MSA

In the tension-type stresses formed in trabecular models, no significant difference was revealed.

bone and graft material, in all models, Group A implants

In the tension-type stresses formed in trabecular led to significantly less stress in comparison to Group $X$ bone and graft material, no significant difference was implants. As the A2 model was generating stress with 5.7 revealed except for the A2 model where MSA was done. Mpa value in trabecular bone and almost half of the As the A2 model generated stress with 2.4 Mpa value in other models, similarly, the A2 model with 5.9 Mpa value trabecular bone and almost half of the other models, formed on the graft material led to less stress in similarly, the A2 model with 4.4 Mpa value formed on the comparison to the X2 model generating $12.4 \mathrm{MPa}$ stress. graft material led to less stress compared to the X2 model generating $7.5 \mathrm{MPa}$ stress.

Table 3: Tension stress values (Pmax)

\begin{tabular}{|c|c|c|c|c|c|c|}
\hline $\begin{array}{c}\text { Compressive } \\
\text { Stresses } \\
\text { (Pmin) }\end{array}$ & $\begin{array}{c}\text { Vertıcal } \\
\text { (Cortical) }\end{array}$ & $\begin{array}{c}\text { Vertical } \\
\text { (Trabecul } \\
\text { ar) }\end{array}$ & $\begin{array}{c}\text { Oblıque } \\
\text { (Cortical) }\end{array}$ & $\begin{array}{c}\text { Oblıque } \\
\text { (Trabecular) }\end{array}$ & \multicolumn{2}{|c|}{ GRAFT MATERIAL } \\
\hline Model X1 & -39.5 & -7 & -91.2 & -8.5 & \multicolumn{2}{|c|}{---- } \\
\hline Model A1 & -25.2 & -7.1 & -60.2 & -7.9 & \multicolumn{2}{|c|}{---- } \\
\hline \multirow[t]{2}{*}{ Model X2 } & \multirow[t]{2}{*}{-43.1} & \multirow[t]{2}{*}{-4} & \multirow[t]{2}{*}{-91.7} & \multirow[t]{2}{*}{-6.7} & Vertical & Oblique \\
\hline & & & & & -8.1 & -7.4 \\
\hline Model A2 & -28.5 & -4.2 & -62.5 & -4.2 & -8.4 & -7.8 \\
\hline
\end{tabular}

Table 4: Compressive stresses (Pmin)

\begin{tabular}{|c|c|c|c|c|c|c|}
\hline $\begin{array}{l}\text { Tensıon } \\
\text { Stresses (Pmax) }\end{array}$ & $\begin{array}{l}\text { Vertıcal } \\
\text { (Cortical) }\end{array}$ & $\begin{array}{l}\text { Vertical } \\
\text { (Trabecular) }\end{array}$ & $\begin{array}{l}\text { Oblıque } \\
\text { (Cortical) }\end{array}$ & $\begin{array}{l}\text { Oblıque } \\
\text { (Trabecular) }\end{array}$ & \multicolumn{2}{|c|}{ Graft Materıal } \\
\hline Model X1 & 17 & 5.1 & 63.8 & 9.7 & \multicolumn{2}{|l|}{----} \\
\hline Model A1 & 22 & 5 & 57.4 & 6.5 & \multicolumn{2}{|l|}{----} \\
\hline \multirow[t]{2}{*}{ Model X2 } & \multirow[t]{2}{*}{17.9} & \multirow[t]{2}{*}{5.3} & \multirow[t]{2}{*}{60.5} & \multirow[t]{2}{*}{10.5} & Vertical & Oblique \\
\hline & & & & & 7.5 & 12.4 \\
\hline Model A2 & 23.4 & 2.4 & 56.9 & 5.7 & 4.4 & 5.9 \\
\hline
\end{tabular}

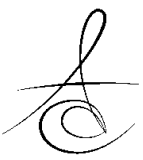



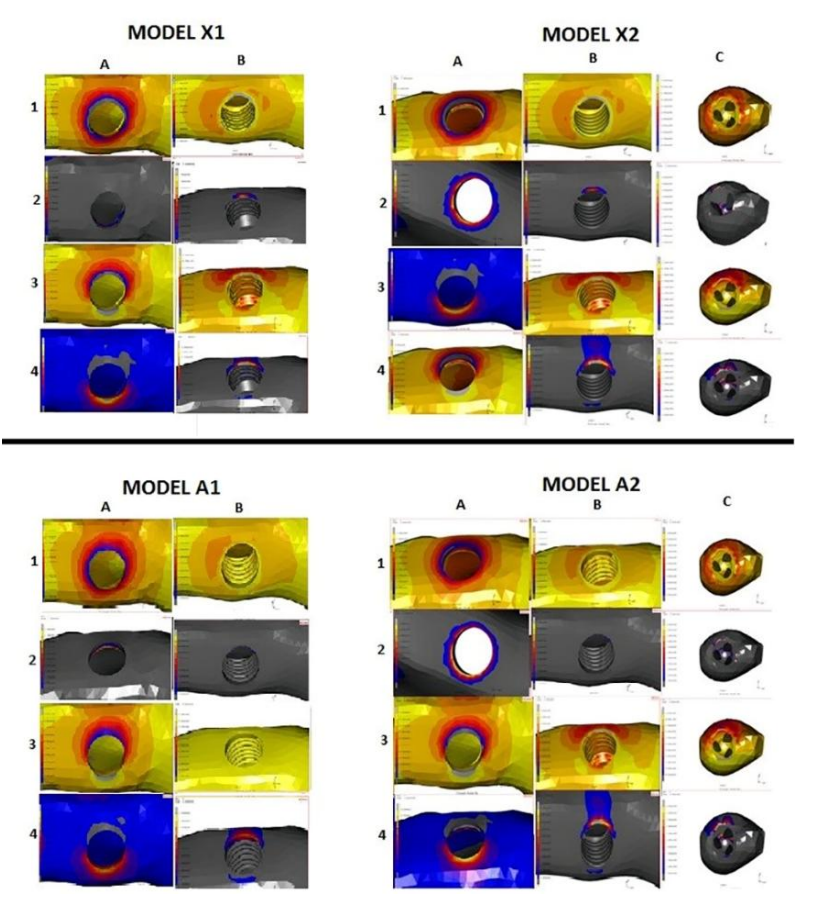

Figure 3. Finite analysis of the 3D models (1: Vertical Pmax, 2: Vertical Pmin, 3: Oblique Pmax, 4: Oblique Pmin) (A: Cortical, B: Trabecular, C: Graft)

\section{Compression (Pmin) Values}

When Group X and A models were compared based on the results obtained in the compression-type stresses occurring in cortical bone as a result of oblique loading, significantly less stress formation was measured in Group A models. When MSA models were compared, the implant in the $\mathrm{X} 2$ group led to more stress formation in comparison to the A2 group. The results were also similar in the control groups.

In the tension-type stresses formed in trabecular bone and graft material, no significant difference was revealed except for the A2 model. Only the A2 group led to less stress in the trabecular bone in comparison to the other groups. The stress values formed on the graft material were quite close in the $\mathrm{A} 2$ and $\mathrm{X} 2$ groups.

Comparison of the Stresses Formed by

\section{Oblique and Vertical Loadings}

When comparisons were made according to the applied force type in all groups, Pmax and Pmin stress values occurring as a result of oblique loading were significantly higher in comparison to the values occurring as a result of vertical loading.

\section{DISCUSSION}

In recent years, many finite element analysis (FEA) studies have been conducted to investigate how the implant-supported prostheses affect the distribution of stress in bones ${ }^{4,} 6,7,10-12$. The reliability of FEA has been compared to other methods and compatible results have been obtained ${ }^{13}, 14$. In this study, using the facilities provided by contemporary technology, the models were prepared in a manner staying loyal to real anatomy, in $3 \mathrm{D}$ and as quite detailed. On the other hand, FEA studies have some restrictions which arise from the technical deficiencies in some points of imitating real life conditions ${ }^{7}$. In this study, accepting the osseointegration as $100 \%$ at the implant bone interface was one of the limitations. However, in the clinical studies that examine the osseointegration degrees where MSA is performed and implants are placed after a certain healing time, there was no evidence of a relationship between boneimplant contact area percentage and stress distribution ${ }^{15}$.

Since the MSA process was first described by Tatum $^{16}$, the success rates have gradually increased. According to Al-Nawas et $\mathrm{al}^{17}$, the success rates of MSA procedures are over $97 \%$. The mechanical features of the graft material play an important role in stress transmission. It is stated that the use of xenograft grafts alone provides intensive bone formation by preserving the volume generated and preventing premature resorption in the augmented region ${ }^{17}$. In the light of this information, in this study, xenograft graft material was simulated and the implant surfaces were modeled as totally covered with graft.

The forces acting on the implant due to direct contact of the implants to the bone were directly transmitted to the surrounding bone tissue. By detecting the forces that may be harmful over these via the receptors in the periodontal ligaments, as the natural teeth can control reflexively, dental implants did not have such a mechanism ${ }^{18}$. Therefore, the bone tissue should be evaluated carefully, and then the implants with the appropriate design should be selected, which will transmit minimal stress to the implant body and surrounding tissues ${ }^{4,19}$.

Thread step, thread depth and thread shape are the most important factors in implant design. Thread shapes may show too much diversity. However, "V" shaped, square-shaped and reverse angled thread forms are being used frequently. In

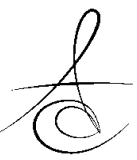


conventional engineering applications, the V-thread design is called a "fixture" and primarily used for fixating metal parts together, not for load transfer. The square thread provides an optimized surface area for intrusive compressive load transmission ${ }^{19}$. The most important goal in the thread geometries is transmitting the forces by reducing which comes over the implant and decreasing cutting-type stresses, which are the most destructive forces on the bone-implant interface. Therefore, the effectiveness of each thread design is different $^{4}$. Geng et al. $^{20}$ reported that the squareshaped thread design transmits less compression and cutting-type forces to tissues in comparison to the " $V$ " shaped and reverse angle-shaped threads. It was also advised that implants with " $\mathrm{V}$ " shaped and large square threads may be used in trabecular bone. Steigenga et al. ${ }^{1}$ also reported that the implants with square threads cause better stress transmission. In their animal study, which compared the removal torque values of the osseointegrated implants with square, "V" shaped and reverse angled threads, it was seen that the implant with square thread form reached the maximum torque value.

In this study, less stress formation was measured in trabecular bone with implants formed with square threads. The reason for this may be the increased surface of the square thread form, and in accordance with this, provision of more contact with graft material and trabecular bone. On the other hand, in the cortical bone, the tension-type stresses were close in each of the two thread forms. The reason for this may be the thin cortical bone in all models $(1 \mathrm{~mm})$ and less thread area in contact with the cortical bone.

\section{CONCLUSION}

According to the results obtained within the limits of this study; Different thread designs influenced formation of stress differently. The implant design with " $V$ " shaped thread caused more stress formation in trabecular bone and graft material in comparison to the square thread form. Moreover, the tension and compression stress values were the highest in the cortical bone layer, less in graft material and minimum in the trabecular bone. Furthermore, the stress values generated in oblique loading were found higher than the stress values generated in vertical loading. In the graft material, the tension stresses were higher than the compression stresses, and the stress values were significantly higher than the trabecular bone

\section{REFERENCES}

1. Steigenga JT, al-Shammari KF, Nociti FH, Misch CE, Wang HL. Dental implant design and its relationship to long-term implant success. Implant Dent. 2003;12:306-17.

2. Jung UW, Hong JY, Lee JS, Kim CS, Cho KS, Choi $\mathrm{SH}$. A hybrid technique for sinus floor elevation in the severely resorbed posterior maxilla. J Periodontal Implant Sci. 2010;40:76-85.

3. Sahin S, Cehreli MC, Yalcin E. The influence of functional forces on the biomechanics of implantsupported prostheses--a review. J Dent. 2002;30:271-82.

4. Bozkaya D, Muftu S, Muftu A. Evaluation of load transfer characteristics of five different implants in compact bone at different load levels by finite elements analysis. J Prosthet Dent. 2004;92:52330.

5. Nelson SJ, Ash MM. Wheeler's Dental Anatomy, Physiology and Occlusion. 9 ed: Saunders; 2009.

6. Huang $\mathrm{HL}$, Fuh $\mathrm{L}$, Ko CC, Hsu JT, Chen CC. Biomechanical effects of a maxillary implant in the augmented sinus: a three-dimensional finite element analysis. Int J Oral Maxillofac Implants. 2009;24:455-62.

7. Tepper G, Haas R, Zechner W, Krach W, Watzek G. Three-dimensional finite element analysis of implant stability in the atrophic posterior maxilla: a mathematical study of the sinus floor augmentation. Clin Oral Implants Res. 2002; 13:657-65.

8. Fanuscu MI, Vu HV, Poncelet B. Implant biomechanics in grafted sinus: a finite element analysis. J Oral Implantol. 2004;30:59-68.

9. Fanuscu MI, Iida K, Caputo AA, Nishimura RD. Load transfer by an implant in a sinus-grafted maxillary model. Int J Oral Maxillofac Implants. 2003;18:667-74.

10. Geng JP, Xu DW, Tan KB, Liu GR. Finite element analysis of an osseointegrated stepped screw dental implant. J Oral Implantol. 2004;30:223-33.

11. Geramy A, Morgano SM. Finite element analysis of three designs of an implant-supported molar crown. J Prosthet Dent. 2004;92:434-40. 
12. Ramoğlu S, Ozan O. Finite element methods in dentistry. J Dent Fac Atatürk Uni. 2014;Supplement: 9:175-80.

13. Trivedi S. Finite element analysis: $A$ boon to dentistry. J Oral Biol Craniofac Res. 2014;4:200-3.

14. Szwedowski TD, Whyne CM, Fialkov JA. Toward characterization of craniofacial biomechanics. J Craniofac Surg. 2010;21:202-7.

15. Lundgren S, Rasmusson L, Sjostrom M, Sennerby L. Simultaneous or delayed placement of titanium implants in free autogenous iliac bone grafts. Histological analysis of the bone graft-titanium interface in 10 consecutive patients. Int J Oral Maxillofac Surg. 1999;28:31-7.

16. Tatum $\mathrm{H}$, Jr. Maxillary and sinus implant reconstructions. Dent Clin North Am. 1986;30:20729.

17. Al-Nawas B, Schiegnitz E. Augmentation procedures using bone substitute materials or autogenous bone - a systematic review and metaanalysis. Eur J Oral Implantol. 2014;7 Suppl 2:S219-34.

18. Akpinar I, Anil N, Parnas L. A natural tooth's stress distribution in occlusion with a dental implant. J Oral Rehabil. 2000;27:538-45.

19. Chowdhary R, Halldin A, Jimbo R, Wennerberg A. Evaluation of stress pattern generated through various thread designs of dental implants loaded in a condition of immediately after placement and on osseointegration--an FEA study. Implant Dent. 2013;22:91-6.

20. Geng JP, Ma QS, Xu W, Tan KB, Liu GR. Finite element analysis of four thread-form configurations in a stepped screw implant. J Oral Rehabil. 2004;31:233-9.

\author{
Yazışma Adresi \\ Sercan KÜÇÜKKURT \\ Istanbul Aydın University, \\ Faculty of Dentistry, \\ Department of Oral and Maxillofacial Surgery, \\ ISTANBUL - TURKEY \\ TI: +90 5326205590 , \\ e-mail: sercankucukkurt@aydin.edu.tr ,
}

